\title{
STUDIES ON AMINO ACID METABOLISM. III. PLASMA GLYCINE CONCENTRATION AND HIPPURIC ACID FORMATION FOLLOWING THE INGESTION OF BENZOATE ${ }^{1}$
}

\author{
By A. de VRIES and B. ALEXANDER, with the technical assistance of Y. QUAMO \\ (From the Medical Research Laboratory, Beth Israel Hospital, and the Department of Medicine, \\ Harvard Medical School, Boston)
}

(Received for publication January 16, 1948)

The conjugation of benzoic acid with glycine, resulting in the formation of hippuric acid, takes place in liver (1) and kidney (2). The urinary output of this conjugate after the administration of benzoate is used to measure this aspect of hepatic function (3).

Theoretically, decreased hippuric acid formation may be due to hepatic and/or renal disease or to an inadequate supply of glycine. In this regard it is not clear to what extent this amino acid is available as such in the liver or is formed ad hoc, either in this organ or elsewhere. The present investigation was undertaken in the hope that data bearing on this question might be obtained.

\section{PROCEDURE AND METHODS}

Six or 10 gms. of sodium benzoate 2 were given orally to fasting normal or diseased subjects, who were induced to drink approximately $500 \mathrm{cc}$. of water. The urine collected during the subsequent three hours was analyzed for its hippuric acid content according to the method of Quick (5). Fasting venous blood was obtained just before the ingestion of benzoate and at intervals thereafter. In some cases an additional fasting sample was taken one-half or one hour before the administration of benzoate. Plasma glycine was determined by the method of Alexander et al. (6). The influence of orally administered glycine was also studied in a few cases.

\section{RESULTS}

Benzoate was administered without additional glycine 11 times to ten individuals (Table I), and in all instances except one (No. 11) a significant decrease in plasma glycine occurred. In some cases the decline began within $3 / 4$ hour after ingestion and continued thereafter (Nos. 1, 2, 7, 8, 9). In others it remained at the low level reached

\footnotetext{
1 Supported by a grant from the John and Mary Markle Foundation, New York City.

2 Sodium benzoate was used in preference to benzoic acid because of its more rapid absorption from the intestinal tract (4).
}

within one hour (Nos. $3,4,10$ ) ; in two subjects (Nos. 5,6 ) it started to rise again during the period of observation. The largest drop in plasma glycine amounted to $2.04 \mathrm{mgm}$. per cent (52 per cent of the initial concentration) ; in general, howover, the extent of the drop was between 20 and 32 per cent of the fasting glycine concentration, and was unrelated to this value.

The amounts of hippuric acid excreted varied widely. It is seen that in the only case in which no decrease in plasma glycine occurred, the hippuric acid excretion was definitely subnormal (1.92 gms., as compared with a minimal normal excretion of 3 gms:) It appears, however, from a comparison of cases 9 and 11 , and 2 and 5 , that no positive correlation exists between the quantity of excreted hippuric acid and the decrease in plasma glycine, although admittedly the number of observations is too limited to permit drawing definite conclusions.

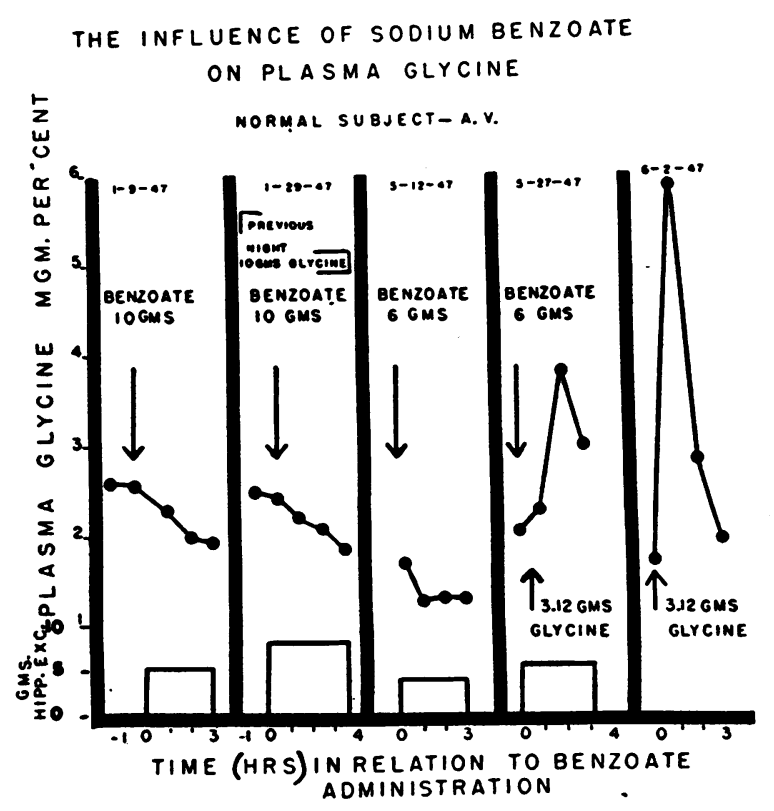

FIG. 1. 
Five experiments were performed on one normal subject (Nos. 2, 3, 12, 13, 13a). The data are presented in Figure 1. The ingestion of 10 gms. of benzoate resulted in a larger hippuric acid excretion and a greater absolute drop in plasma glycine than the administration of 6 gms. Fur- thermore, the ingestion of 10 gms. of glycine the night prior to the test resulted in a larger hippuric acid excretion, without, however, a greater decline in plasma glycine than obtained following the administration of $10 \mathrm{gms}$. of benzoate alone. The administration of glycine half an hour after the

TABLE I

The effect of benzoate on plasma glycine and on hippuric acid formation

\begin{tabular}{|c|c|c|c|c|c|c|c|c|c|}
\hline \multirow[b]{2}{*}{ 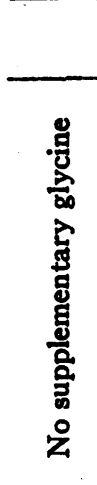 } & No. & Sub. & Sex & Age & Diagnosis & $\underset{\text { taken }}{\text { Na benz. }}$ & \multicolumn{2}{|c|}{$\underset{\text { excretion }}{\text { Hipp.acid }}$} & $\begin{array}{l}\text { Urine } \\
\text { vol. }\end{array}$ \\
\hline & $\begin{array}{r}1 \\
2 \\
3 \\
4 \\
5 \\
6 \\
7 \\
8 \\
9 \\
10 \\
11\end{array}$ & $\begin{array}{l}\text { M. G. } \\
\text { A. V. } \\
\text { A. V. } \\
\text { F. B. } \\
\text { W. T. } \\
\text { L. S. } \\
\text { I. G. } \\
\text { S. R. } \\
\text { E.A. } \\
\text { Th. W. } \\
\text { P. J. }\end{array}$ & $\begin{array}{l}\mathrm{F} \\
\mathbf{M} \\
\mathbf{M} \\
\mathbf{M} \\
\mathbf{M} \\
\mathbf{M} \\
\mathbf{M} \\
\mathbf{F} \\
\mathbf{M} \\
\mathbf{M}\end{array}$ & $\begin{array}{l}21 \\
35 \\
35 \\
44 \\
60 \\
70 \\
43 \\
49 \\
32 \\
52 \\
25\end{array}$ & $\begin{array}{l}\text { Bronchial asthma } \\
\text { Normal (1-9-47) } \\
\text { Normal }(5-12-47) \\
\text { Essential hypertension } \\
\text { Arterioscler.; heart disease, congestive } \\
\text { failure } \\
\text { Infectious hepatitis } \\
\text { Infectious hepatitis } \\
\text { Car. of pancreas } \\
\text { Nutrit. hypoproteinemia } \\
\text { Virus pneumonia; malnutrition. Recon- } \\
\text { valescent (5-8-47). } \\
\text { Rheumatoid arthritis }\end{array}$ & $\begin{array}{c}\text { gms. } \\
10 \\
10 \\
6 \\
10 \\
6 \\
6 \\
6 \\
6 \\
6 \\
6 \\
6\end{array}$ & $\begin{array}{l}\text { gms. } \\
\\
5.10 \\
3.77 \\
\\
3.48 \\
4.15 \\
4.28 \\
4.2 \\
2.03 \\
2.61 \\
1.92\end{array}$ & $\begin{array}{l}\text { hrs. } \\
3 \\
3 \\
3 \\
3 \\
3 \\
3 \\
4 \\
3 \\
3\end{array}$ & $\begin{array}{l}c c . \\
440 \\
360 \\
355 \\
950 \\
310 \\
300 \\
200 \\
230 \\
380\end{array}$ \\
\hline 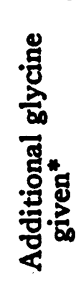 & $\begin{array}{l}12 \\
13 \\
13 a \\
14\end{array}$ & $\begin{array}{l}\text { A. V. } \\
\text { A. V. } \\
\text { A. V. } \\
\text { Th. W. }\end{array}$ & $\begin{array}{l}\mathbf{M} \\
\mathbf{M} \\
\mathbf{M} \\
\mathbf{M}\end{array}$ & $\begin{array}{l}35 \\
52 \\
\cdot\end{array}$ & $\begin{array}{l}\text { Normal (1-29-47); } 10 \text { gms. glycine taken } \\
\text { night before test } \\
\text { Normal ( } 5-27-47) ; 3.12 \text { gms. glycine taken } \\
\text { 1 hour af ter ingestion of } 6 \text { gms. Na } \\
\text { benzoate } \\
\text { Normal (6-2-47); } 3.12 \text { gms. glycine w/o Na } \\
\text { benzoate } \\
\text { Virus pneumonia; malnutrit. Reconva- } \\
\text { lescent. 3.12 gms. glycine taken simul- } \\
\text { taneously w/ } 6 \text { gms. Na benzoate }\end{array}$ & $\begin{array}{r}10 \\
6\end{array}$ & $\begin{array}{l}7.69 \\
5.18\end{array}$ & $\begin{array}{l}3 \frac{1}{4} \\
3 \frac{1}{4}\end{array}$ & $\begin{array}{l}300 \\
445\end{array}$ \\
\hline
\end{tabular}

TABLE I-Continued

\begin{tabular}{|c|c|c|c|c|c|c|c|c|c|c|c|c|c|c|c|c|c|c|c|c|c|c|}
\hline & \multirow{3}{*}{ No. } & \multirow{3}{*}{ Sub. } & \multicolumn{5}{|c|}{$\begin{array}{c}\text { Plasma glycine-mgm. per cent } \\
\text { Fasting }\end{array}$} & \multicolumn{13}{|c|}{$\begin{array}{l}\text { Plasma glycine-mgm. per cent } \\
\text { After benzoate ingestion }\end{array}$} & \multirow{2}{*}{\multicolumn{2}{|c|}{$\begin{array}{l}\text { Plasma } \\
\text { glycine } \\
\text { decrease }\end{array}$}} \\
\hline & & & & Time & in $\mathrm{mi}$ & autes & & & & & & & Tim & $\mathrm{e}$ in $\mathrm{m}$ & inutes & & & & & & & \\
\hline & & & -60 & -45 & -30 & -15 & 0 & 15 & 30 & 45 & 60 & 75 & 90 & 105 & 120 & 135 & 150 & 165 & 180 & 195 & & \\
\hline 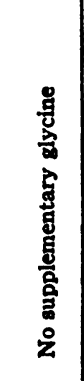 & $\begin{array}{r}1 \\
2 \\
3 \\
4 \\
5 \\
6 \\
7 \\
8 \\
9 \\
10 \\
11\end{array}$ & $\begin{array}{l}\text { M. G. } \\
\text { A. V. } \\
\text { A. V. } \\
\text { F. B. } \\
\text { W. T. } \\
\text { L. S. } \\
\text { I. G. } \\
\text { S. R. } \\
\text { E. A. } \\
\text { Th. W. } \\
\text { P. J. }\end{array}$ & $\begin{array}{l}2.61 \\
2.19\end{array}$ & $\begin{array}{l}2.66 \\
1.99 \\
1.44\end{array}$ & $\begin{array}{l} \\
1.91 \\
3.86 \\
1.26\end{array}$ & . & $\begin{array}{l}2.47 \\
2.56 \\
1.65 \\
2.06 \\
2.10 \\
2.17 \\
1.99 \\
1.85 \\
3.90 \\
1.33 \\
1.29\end{array}$ & & $\begin{array}{l}2.27 \\
\\
1.75 \\
2.81\end{array}$ & $\begin{array}{l}1.82 \\
1.56 \\
1.70\end{array}$ & $\begin{array}{l}1.27 \\
1.37 \\
1.61 \\
\\
0.92 \\
1.22\end{array}$ & & 1.99 & $\begin{array}{c}1.65 \\
1.47\end{array}$ & $\begin{array}{l}1.33 \\
1.15 \\
1.61 \\
1.45 \\
2.17 \\
0.88 \\
1.20\end{array}$ & & 1.91 & 1.48 & $\begin{array}{l}1.30 \\
1.42 \\
1.91 \\
1.41 \\
\\
0.84 \\
1.28\end{array}$ & 1.86 & \begin{tabular}{|c|} 
mgm. \\
per \\
cent \\
0.82 \\
0.65 \\
0.35 \\
0.58 \\
0.68 \\
0.26 \\
0.58 \\
0.40 \\
2.04 \\
0.49 \\
0
\end{tabular} & $\begin{array}{l}\text { per } \\
\text { cent } \\
33 \\
21 \\
21 \\
28 \\
32 \\
12 \\
29 \\
22 \\
52 \\
37 \\
0\end{array}$ \\
\hline 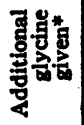 & $\begin{array}{l}12 . \\
13 \\
13 \mathrm{a} \\
14\end{array}$ & $\begin{array}{l}\text { A. V. } \\
\text { A. V. } \\
\text { A. V. } \\
\text { Th. W. }\end{array}$ & & 2.49 & & & $\begin{array}{l}2.41 \\
2.02 \\
1.69 \dagger \\
1.73 \dagger\end{array}$ & & 5.84 & & $\begin{array}{l}2.19 \\
2.31 \\
2.89\end{array}$ & & 2.78 & & $\begin{array}{l}2.10 \\
3.80 \\
2.60\end{array}$ & & 1.91 & & $\begin{array}{l}1.82 \\
2.99 \\
2.00\end{array}$ & & 0.59 & 24 \\
\hline
\end{tabular}


benzoate ingestion in an amount equivalent (chemically) to the benzoate ingested also increased the hippuric acid output; plasma glycine rose, but to a lesser extent than when glycine alone was administered.

The influence of additional glycine on hippuric acid formation was also apparent in subject $T h$. W. (compare No. 10 with Nd. 14 of the table).

\section{DISCUSSION}

Leuthardt and Glasson (7) and Quick (1) assumed that the glycine needed for the conjugation of benzoic acid is synthesized by the liver at a rate which is the principal limiting factor in hippuric acid synthesis. It has been known $(1,8-11)$ and reconfirmed above that the administration of glycine in addition to benzoate increases hippuric acid formation. In senile individuals, subnormal hippuric acid formation may be due to inability of the liver to furnish enough glycine since supplements of this amino acid restore hippurate excretion to normal (12).

That stores of free glycine are present in the body has been shown $(13,14)$. The drop in plasma glycine occurring after benzoate administration, first reported by Christensen (14) and confirmed by us, indicates that these stores are utilized in hippuric acid formation probably faster than the amino acid can be synthesized or mobilized. The question arises if and to what extent the concentration of plasma glycine influences the synthesis of hippuric acid. The subnormal hippuric acid output and absence of plasma glycine drop in Case No. 11, whose fasting plasma glycine was extremely low, can be interpreted in two ways: either not enough glycine, as reflected by the low plasma glycine concentration, was available for hippuric acid formation, or a primary disturbance in liver function of this patient prevented glycine-benzoate conjugation. In accord with the latter concept is the decline of plasma glycine in Case No. 10, whose fasting plasma glycine was also subnormal.

It appears that an elevated blood glycine concentration consequent to glycine ingestion (compare No. 3 with 13,11, and with 14) is accompanied by increased hippuric acid formation. A high plasma glycine level per se, however, does not necessarily result in a very large hippuric acid output even though a considerable drop in plasma glycine may occur after benzoate ingestion (No. 9). It would thus seem that the concentration of plasma glycine cannot be considered an absolute measure of the total amount of glycine available for uptake by the liver (and kidney?). The net decrease in plasma glycine following benzoate administration may be influenced not only by uptake by the liver but also by other factors such as plasma volume, and by the rate of replacement of plasma glycine by tissue stores of the amino acid, In this respect it is noteworthy that the subject of Experiment 9 had an exceptionally low body weight and, accordingly probably a low plasma volume. Furthermore, an intravenous glycine tolerance test on this subject (reported elsewhere [15]) indicated a slow equilibration of plasma glycine with the tissues. It should be pointed out, however, that because of the low body weight 6 gms. of benzoate in this patient would be comparable to a much larger dose in heavier subjects.

That glycine given simultaneously with benzoate is utilized for hippuric acid synthesis is indicated not only by increased hippuric acid formation but also by a smaller rise in plasma glycine than when the same amount of amino acid is given alone. On the other hand, the rise which did occur, even when glycine was simultaneously administered in amounts chemically equivalent to the ingested benzoate, indicates that part of the ingested glycine was not utilized during the observation period. This is probably attributable to a faster rate of glycine absorption than benzoic-glycine conjugation, whatever the limiting factors of the latter may be.

The large hippurate excretion observed when glycine was taken the night prior to benzoate suggests that glycine was stored in the liver (and kidney?) either in free, or in otherwise readily available form. The latter is more probable since it is known that three hours after glycine injection the concentration of easily extractable amino acids in the liver has returned to normal (16).

From the data it appears that within certain limits the rate of conjugation of benzoate with glycine depends to some extent upon both the dose of benzoate and the availability of glycine in the body. Under certain conditions the latter may be significantly curtailed. Accordingly, to obviate these factors in hippuric acid studies of liver function, it might be advantageous to administer 
the benzoate in doses determined by the total body weight or surface area and to give the amino acid before or with the benzoate in at least a chemically equivalent amount.

\section{CONCLUSIONS}

1. In ten out of 11 experiments the administration of sodium benzoate resulted in a decrease in plasma glycine concentration. In one case with subnormal hippuric acid excretion the plasma glycine remained unaltered.

2. The administration of glycine before or together with the benzoate results in a larger output of hippuric acid than when benzoate alone is ingested.

3. The rate of conjugation of glycine to benzoate, the availability of glycine for this purpose, and the size of the dose of benzoate, are important factors which affect hippuric acid synthesis in man:

\section{BIBLIOGRAPHY}

1. Quick, A. J., The conjugation of benzoic acid in man. J. Biol. Chem., 1931, 92, 65.

2. Snapper, I., Grünbaum, A., and Neuberg, J., Über die Hippursäuresynthese in der überlebenden Niere von verschiedenen Tiergattungen, auch vom Menschen. Biochem. Ztschr., 1924, 145, 40.

3. Quick, A. J., The clinical application of the hippuric acid and the prothrombin tests. Am. J. Clin. Path., 1940, 10, 222.

4. Snapper, I., and Saltzman, A., Quantitative aspects of benzoylglucuronate formation in normal individuals and in patients with liver disorders. Am. J. of Med., 1947, 2, 327.

5. Simmons, J. S., and Gentzkow, C. J., Laboratory Methods of the United States Army. Lea \& Febiger, Philadelphia, 1944, Ed. 5, p. 6.
6. Alexander, B., Landwehr, G., and Seligman, A. M., A specific micromethod for the colorimetric determination of glycine in blood and urine. J. Biol. Chem., 1945, 160, 51.

7. Leuthardt, F., and Glasson, B., Formation du glycocolle à partir de la serine. Helv. Chim. Acta, 1942, 25, 245.

8. Griffith, W. H., and Lewis, H. B., Studies in the synthesis of hippuric acid in the animal organism. $V$. The influence of amino-acids and related substances on the synthesis and rate of elimination of hippuric acid after the administration of benzoate. J. Biol. Chem., 1923, 57, 1.

9. Kingsbury, F. B., The synthesis and excretion of hippuric acid: the glycine factor. Proc. Soc. Exper. Biol. \& Med., 1922-23, 20, 405.

10. Csonka, F. A., On the administration of various proteins with benzoic acid to a pig. J. Biol. Chem., 1924, 60, 545.

11. Abderhalden, E., and Strauss, H., Beitrag zur Kenntnis des Umfanges der Hippursäurebildung im Organismus des Schweines. Z. Physiol. Chem., 1914, $91,81$.

12. Stern, K., Tyhurst, J. S., and Askonas, B. A., Note on hippuric acid synthesis in senility. Am. J. Med. Sc., 1946, 212, 302.

13. Gutman, G. E., and Alexander, B., Studies of amino acid metabolism. I. Blood glycine and alanine and their relationship to the total amino acids in normal subjects. J. Biol. Chem., 1947, 168, 527.

14. Christensen, H. N., Cooper, P. F., Johnson, R. D., Jr., and Lynch, E. L., Glycine and alanine concentrations of body fluids; experimental modification. J. Biol. Chem., 1947, 168, 191.

15. de Vries, A., and Alexander, B., Studies on amino acid metabolism. II. Blood glycine and total amino acids in various pathological conditions, with observations on the effects of intravenously administered glycine. J. Clin. Invest., 1948, 27, 655.

16. van Slyke, D. D., and Meyer, G. M., The fate of protein digestion products in the body. III. The absorption of amino acids from the blood by the tissues. J. Biol. Chem., 1913-14, 16, 197. 